\title{
AUTHORITY-CITIZEN RELATION IN THE ASPECT OF THE DEVELOPMENT OF E-ADMINISTRATION
}

\author{
AGNIESZKA AGATA TOMASZEWICZ
}

University of Szczecin, Faculty of Management and Economics of Services, POLAND

e-mail: agnieszka.tomaszewicz@wzieu.pl

\author{
\begin{tabular}{l|l} 
RECEIVED & 18 January 2018
\end{tabular} \\ \begin{tabular}{l|l} 
ACCEPTED & 2 September 2018
\end{tabular} \\ JEL \\ CLASSIFICATION \\ $\mathrm{D} 83, \mathrm{O} 35, \mathrm{O} 38$
}

KEYWORDS Internet communication, e-administration, virtual community

ABSTRACT The growing ICT awareness and growing equipment in the information and communication tools of the society are conducive to and at the same time force the development of e-administration. In communication on the authority-citizen line, the ICT system is increasingly being used as the basis for the development of e-administration. Along with the further development of the Internet, this form of communication will become widespread and will undergo intensification. The article is a theoretical review and may encourage further research and reflection. Presents the analysis of the importance of Internet communication for the development of e-administration. The purpose of the article is to indicate that the new quality in access to information on public matters means that it is becoming faster and more common. New technologies contribute to its creation, which should be perceived as a tool for the transformation of administration and the way public services are provided, and thus the new way of communicating with the society. This paper, therefore, indicates the importance of communication in the authority-citizen and citizen-authority relation for the development of public e-administration. In addition, it was emphasized that proper communication of administration with citizens is considered as a factor that will determine interest in, and thus the development of e-administration.

\section{Introduction}

New technologies mean that e-administration can be perceived as an element serving the creation of additional public value. Their intensive development, and in particular the development of the Internet, contributed to the emergence of a new approach in communication on the state-citizens line and to the introduction of new solutions, models and services in this area through electronic public administration. 


\section{Litepature review}

The process of building both the information society and the e-administration itself is based, among others, on creating a proper ICT infrastructure that is helpful in the development of the content and system of e-services. Therefore, one of the main conditions for the implementation of e-administration is access to the Internet and its widespread reach (Garson, 2005, p. 27; Luterek, 2010, p. 12). Over the past five years, a dynamic increase in the number of Internet users has been observed from 35 to $53 \%$ for the global population. Currently, the Internet is used by over 4 billion people, on average using it for 6 hours a day (Digital..., 2018, p. 7). Development in this area results in better remote communication possibilities, at the same time leading to the interpenetration of technologies and services that so far have been usually treated separately (Boni, 2009, p. 146; Program, 2013, p. 11).

In Poland, according to previous forecasts, the number of Internet users in 2020 should be around 1827 million (depending on the scenario adopted; Deloitte, 2012), but as data from early 2018 shows, the current Internet penetration is already at $78 \%$, which means that 29.75 million people in Poland use the Internet, and, as research shows, they devote 5 hours 55 minutes per day to it (Digital..., 2018, p. 39). The increasing use of the Internet in everyday life contributes to the creation of an innovative e-economy, the shape of which will be influenced by the development of the government's strategy in the area of public administration e-services, implemented for the needs of business and citizens (Analiza..., p. 5). This clearly determines the increase in the use of the Internet as a stimulant of further development of internetization of public administration (Cyfrowa..., 2013, p. 19).

As recent years show, the rapid development of information technologies leads to a change in the manner and forms of communication, ultimately also affecting the manner and form of providing public services. C.M. Olszak and E. Ziemba are right in their view that the development of the information society is not possible without an efficiently functioning public administration. In addition to improving services, information and communication technologies lead to improved transparency and efficiency of information processes and management, which facilitates planning processes and administrative decision making (Olszak, Ziemba, p. 104). It is also assumed that the basic task of the state in the process of computerization and building of Digital Poland is to support the creation of a proper ICT infrastructure, which is the basis for the development of electronic administration. This is to be achieved by providing universal access to broadband services and creating an efficient infrastructure in the perspective of the next 12 years using the latest information technologies (Polska 2030..., 2012, pp. 100-101). It can be assumed that ICT shape the development of public e-administration allowing for different methods of communication and provide mobile access to and delocalization of services offered. Thanks to them, serving disabled persons is also easier (Program..., 2013, p. 65).

In a modern state, based on the use of new technologies, including the Internet, quick access to information is an indispensable element of citizen's life and a basic service provided to local communities (Strategia..., 2006, p. 60). More and more, communities are demanding simple, fast, remote communication and the possibility to handle their matters using the ICT infrastructure (Społeczeństwo, p. 115; Diagnoza, p. 27). The improvement of the quality of life in the era of the modern world is to a large extent conditioned by the use of information and communication technologies that serve to improve this communication (Hughes et all., 2009, p. 30).

By implementing solutions in the area of e-administration, access to communication between the authorities and citizens becomes easier, and the result of the development of communication with the use of ICT tools is better quality of and tailoring the offer to the consumer's needs, an increase in work efficiency, reduced production costs, and the emergence of new products. Therefore, we should strive to increase access to the Internet and create 
more favorable system conditions for investment in ICT. As public e-administration develops, the range of services offered in contacts with communities via electronic data carriers is growing (Strategia..., 2006, p. 23).

With the evolution of the use of new technologies, it was observed that virtual communities began to be created. They allow communities to freely exchange views and opinions, thanks to which it is possible to create diverse groups of users with common interests. This virtual community according to $\mathrm{M}$. Castells is generally organized around shared interests or goals (Castells, 2008, p. 362). Virtual communities are created by groups connected by a common interest, but separated by distance (Pańkowska, Sroka, 2002, p. 73). According to W. Chmielarz's definition virtual communities are "social groups gathering in the global network, distinguished according to the criterion of common interests, aspirations, desires, intuitions and needs in the implementation of a specific goal (it can also be an exchange of opinions or a community of views)" (Chmielarz, 2007, p. 271).

\section{Method}

The paper is of a theoretical review nature and may encourage further scientific research and reflection. It presents the analysis of the importance of Internet communication for the development of e-administration. The author indicates the role of information and communication technologies in creating a new type of communication on the authority-citizen line. The method used in the work was the analysis of literature and the analysis of content. The author reviewed available publications covering national and foreign literature on the subject, as well as reports and analyses in the field of public e-administration, as well as documents of a legislative nature.

\section{Results}

Due to the increasing access to the Internet, it is assumed that its users will more and more often create virtual groups, uniform in terms of interests, needs, lifestyles, regardless of where they are physically located (Gregor, Stawiszyński, 2002, p. 64). This will be an opportunity to strengthen ties in local communities. The awareness of citizens that they can actually influence the fate of the country and the awareness of freedom in dealing with local communities should theoretically contribute to their active participation in the creation of electronic administration. This should happen because virtual communities are also seen as tools for the development of local democracy. It is argued that discussion forums are an element that sustains the development of civic associations. With regard to public administration, such communication space as the forum allows for the communication of many people, where public affairs can be discussed in public. Virtual communities help citizens learn about public affairs and create centers of political power independent of the central authority. Through virtual communities they can assemble into unions and associations, also in order to speak on public matters. Thanks to the Internet, it becomes possible to transfer the possession of information into citizens' hands, resulting in more effective participation of citizens in public life (Pańkowska, Sroka, 2002, p. 72).

The development of virtual communities may include supporting the development of local budget organizations, interpersonal communication of residents and improving the provision of social services. They also help to create links between the local communities' on-line information services to share knowledge and experience.

At the local self-government level, social communication should provide information to the local community about the activities of commune authorities and of people from the outside of the commune, which means that it should be conducted in an open manner. This is why more and more often the potential of Internet communication is also seen by the self-government authorities themselves, using this channel to inform residents about their 
actions, as well as seeking their opinions. The conscious information policy of local self-government authorities involves proper communication with the environment in order to achieve strategic development goals by obtaining active social support and creating a positive image of the commune. In order to achieve this goal, residents should be involved in the decision-making process. This goal can be achieved through (Sakowicz, 2002, p. 45; Augustyn, Dębowski, 2003, p. 156):

- informing - authorities disseminate information and allow citizens' passive access to information,

- consultation - in the form of a bilateral relationship in which citizens express their opinions and establish a dialogue with those in power,

- active participation - a partnership arrangement, where citizens also take part in the decision-making process, but the responsibility for final decisions and the implementation of the relevant program lies with the authorities.

These goals become easier to implement thanks to modern ICT technologies that can be used by administrative authorities today.

It is true that citizens' trust in the authority is often a prerequisite for introducing various programs and ventures that are innovations, especially on a local scale. Thanks to a properly conducted information policy, it is possible to gain public trust in the authorities. Thus, it can be generally assumed that proper communication between the administration and citizens is considered as a factor that will determine interest in and, hence, the development of e-administration. The more so because the region is more and more often perceived as the source of information, skills and innovation, as an environment reducing uncertainty and risk. It is expected to use the so-called bottom-up, endogenous development factors in local development, leading to the fact that in general the information society is becoming an inherent feature of regional development, including local development (Richter-Kaźmierska, 2008, p. 276).

It should also be noted that further development of the information society is to give the possibility of offering electronic administrative services, therefore it is important to care for digital education, because the increase in the advancement of a number of applications used in electronic administration may result in digital illiteracy, which leads to social exclusion. In order to counteract it, the activation of older persons and the equalization of differences between rural and urban areas are needed in particular. On the other hand, on the administration side conducting employee training is an important element; it should be obligatory in the situation when new systems for the provision of electronic services in the field of e-administration are being implemented.

The process of implementing public e-administration is an instrument to improve the provision of services, it is also the foundation of public governance that involves citizens in public life. In essence, it assumes providing citizens and enterprises with a broad offer of public services via the Internet, which affects serving the community and thus improves communication between entities. It can therefore be assumed that in order for the communication between citizens and the administration in its virtual aspect to affect the latter in its development it should:

- be oriented towards the needs of citizens and entrepreneurs and provide them with high quality services,

- act on the basis of unambiguous and transparent organizational and legal regulations,

- provide universal access, in particular to the provision of public e-services,

- be integrated with the systems of other offices to be able to provide comprehensive services to its clients.

User orientation involves the construction of electronic services serving the user, ones that meet their needs, predispositions and take into account their behavior patterns. The key role in constructing guidelines to 
the creation of an adequate information system should be played by the possibility of proper communication and ensuring efficient service to the local community, which e-administration does in its scope, allowing quicker conduct of internal processes, handling administrative matters and citizens' immediate contact with the authority without having to travel.

As an example of such solutions, we can refer to the concept of "one-stop-shop". Due to the fact that the main area of local government self-government activities includes improvement of communication with authorities at all levels, acceleration of official settlement procedures and, above all, seeking integration of e-services provided to citizens and enterprises by administration units, it is necessary to create the possibility carrying out the work carried out by the client from the beginning to the end, in one place. This concept is called "one-stop-shop".

In Poland should be helpful in its implementation to fully use the planned functionalities of the ePUAP platform, regional platforms, as well as to integrate e-public services provided through thematic platforms. The introduction of this concept will help improve the efficiency of local government self-government by implementing a new type of e-services.

\section{Conclusions}

The development of the information society enforces changes in the traditional approach to administration. Dynamic development, the spread of the use of information and communication technologies and growing ICT awareness will stimulate further growth of the importance of e-administration. Expanding communication with an additional channel, that is the Internet, improves the efficiency of service for the community by introducing enhancements, generating real changes in service that both are beneficial for the community and affect the rise in the quality of the authority's functioning. The scope of changes, including organizational ones, has an impact on the communication of administration with citizens. They affect the relations between public administration bodies and entrepreneurs, citizens or other administrative units.

What is important, e-administration does not only help in creating the very interface between citizens and public administration using information and communication technologies, but above all it builds relationships between them and influences the change in the administration's philosophy, ultimately focusing it on the citizen.

\section{References}

Analiza dobrych praktyk w obszarze e-administracji (2013). Warszawa: Centrum Projektów Informatycznych.

Augustyn, A., Dębowski, T. (2003). Komunikacja społeczna a relacje pomiędzy samorządem lokalnym i mieszkańcami gminy. In: J. Karwowski (ed.), Jakość życia w regionie (p. 156). Szczecin: Uniwersytet Szczeciński.

Boni, M. (ed.) (2009). Polska 2030. Wyzwania rozwojowe. Warszawa: Kancelaria Prezesa Rady Ministrów.

Castells, M. (2008). Społeczeństwo sieci. Warszawa: Wydawnictwo Naukowe PWN.

Chmielarz, W. (2007). Systemy biznesu elektronicznego. Warszawa: Difin.

Cyfrowa przyszłość Polski. Fundamenty rozwoju konkurencyjnej Gospodarki w dobie globalizacji (2013). Report. Amárach research, Deloitte commissioned UPC. Retrieved from: https://www.telepolis.pl/grafika/newsy/2013-12/cyfrowa_przyszlosc_raport.pdf.

Deloitte (2012). Wpływ przyspieszonego rozwoju szerokopasmowego dostępu do Internetu na polską gospodarkę. Warszawa. Retrieved from: http://eregion.wzp.pl/sites/default/files/pl_szerokopasmowy_internet_raport_lipiec_2012.pdf.

Digital in 2018. Essential insights into Internet, Social Media, Mobile, and eCommerce use around the World (2018). We Are Social, Hootsuite. Retrieved from: https://wearesocial.com/blog/2018/01/global-digital-report-2018.

Garson, G.D. (2005). Handbook of Public Information System. Boca Raton: Taylor \& Francis.

Gregor, B., Stawiszyński, M. (2002). e-Commerce. Bydgoszcz: Oficyna Wydawnicza Branta. 
Hughes, G., Assis, J., Cornford, J., Gareis, K., Richardson, R., Sokol, M. (2009). Analiza porównawcza i promowanie transformacyjnego wykorzystania technologii informacyjno-komunikacyjnych (ICT) w regionach Unii Europejskiej. TRANSFORM project, Biblioteka eRozwoju. Tarnów: Stowarzyszenie „Miasta w Internecie”.

Luterek, M. (2010). e-government. Systemy informacji publicznej. Warszawa: Wydawnictwo Akademickie i Profesjonalne.

Olszak, C.M., Ziemba, E. (2010). Strategia rozwoju społeczeństwa informacyjnego w regionie. Aspekt e-administracji. In: B. Kos (ed.), Transformacja gospodarki-konsumenci, przedsiębiorstwa, regiony (p. 104). Studia Ekonomiczne, Wydziałowe ZN Uniwersytetu Ekonomicznego w Katowicach.

Pańkowska, H., Sroka, M. (eds.) (2002). Systemy informatyczne organizacji wirtualnych. Katowice: Wydawnictwo Akademii Ekonomicznej w Katowicach.

Polska 2030. Trzecia fala nowoczesności. Długookresowa Strategia Rozwoju Kraju (2012). Warszawa: Ministerstwo Administracji i Cyfryzacji.

Program Zintegrowanej Informatyzacji Państwa (2013). Warszawa: Ministerstwo Administracji i Cyfryzacji.

Richert-Kaźmierska, A. (2008). Społeczeństwo informacyjne w rozwoju regionalnym. In: J. Goliński, K. Krauze (eds.), Współczesne aspekty informacji (p. 276). Monografie i Opracowania, 551. Warszawa: Szkoła Główna Handlowa.

Sakowicz, M. (2002). Polityka informacyjna władz lokalnych. Wspólnota, 10, 45.

Strategia Rozwoju Kraju 2007-2015 (2006). Warszawa: Ministerstwo Rozwoju Regionalnego.

Cite this anticle aS: Tomaszewicz, A.A. (2018). Authority-citizen relation in the aspect of the development of e-administration. European Journal of Service Management, 3 (27/2), 483-488. DOI: 10.18276/ejsm.2018.27/2-59. 